\title{
Lagrange粒子付Euler型スキームを用いた 衝撃圧による構造物の動的応答解析
}

\author{
正員陸 田 秀 実 ${ }^{*}$ 非正員新蔵 慶 昭* 正員 土井康 明
}

N umerical Simulation of Dynamic Response of Structure Caused by Impact Pressure

$U$ sing an Eul erian Scheme with L agrangian Particles

by Hidemi M utsuda, M ember Y Yoshiaki Shinkura, Y $\quad$ asuaki Doi, M ember

\begin{abstract}
Summary
We have developed a new numerical scheme that combines a Eulerian scheme with Lagrangian particles to compute fluid-structure interaction caused by impact pressure. The proposed numerical model was applied to several problems such as interaction between a solid structure with dam breaking, and hydroelastic due to impact pressure acting on a vertical wall. The Lagrangian particles are useful and available to capture an interface between different phases. The model can estimate impact pressure acting on a vertical wall, its deformation, vibration, stress and strain. We made clear three dimensional impact pressure field of solid structure in space and time and advantageous effect of artificial stress term.
\end{abstract}

\section{1. 緒 論}

船舶海洋工学分野において，特に耐航性，耐波性を評価す る際, 構造物と流体が相互作用する力学現象が重要となる. 例えば，船舶・海洋構造物に巻き波型砕波が作用する場合， 巻き込みジェットと構造物の間に封入された空気塊による 衝撃砕波圧とこれに伴う構造物の動的振動が発生する.この ような非定常な波浪衝撃荷重が作用した場合, 衝突水塊によ る加振力と構造物の振動が共振する可能性もある. Faltinsen ${ }^{1)}$ ，Korobkin²)らは，このような波浪衝撃力を評価す るには，流力弾性応答・振動を考慮することが重要であり， その理論的な取り扱いと設計指針を示している.

このような流体と構造の連成問題を計算力学的に取り扱 うには, Lagrange表記が一般的である構造体（弾性体）の解 析法とEuler表記が一般的である流体の解析法をどのように 融合・整合させるかが問題となる. 任意に移動する構造と流 体の連成界面を追跡する代表的なものにALE (A rbitrary Lagrangian-Eulerian)法 ${ }^{3)}$ PDSD/ST (Deforming Spatial Domain (Space Time) 法 ${ }^{4)}$ がある.この場合, 構造物に大変形が生じる

\footnotetext{
* 広島大学大学院工学研究科

**（株）トヨタコミュニケーションシステム
}

原稿受理 平成 20 年 8 月 29 日
場合や, 流体領域（例えば, 気液界面）の変動が複雑になる 場合には，何らかの対処策（例えば，重合格子法など）が必 要となる。一方, 任意に移動する構造と流体の連成界面に L agrangeマーカー粒子群を配置し複雑界面の模擬に境界埋 め込み法 (IB (Immersed B oundary)法 ${ }^{5)}$ ) を利用するものもあ る。以上の方法は，これまでに数多く適用6),7)がなされてい る。この他，牛島 ${ }^{8)}$ は，格子法にT型剛体モデルとT型質点 モデルを導入し, 流体力によって変形する物体を取り扱う数 值解法を提案している。しかしながら，これらの研究では， 衝撃砕波圧による構造体の変形・振動挙動問題への適用がな

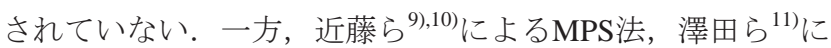
よる重合ALE法によって, 流力弾性連成解析が行われ, 有用 な研究成果が報告されている。しかしながら，このような連 成解析法が, 砕波による衝撃圧と構造体との相互作用問題へ 適用できるか否かは不明である。

そこで本研究では, 船舶・海洋工学分野での固体流体連成 問題に対する数值計算法として, 解析精度の安定性や構造体 の流力弾性変形問題への柔軟性, 3次元拡張性を考慮して, 著者らがこれまで開発してきたEuler型解法に基づく粒子付 界面追跡スキーム ${ }^{12)}$ に, SPH 法 ${ }^{13)}$ による大変形構造解析手法 14)を組み込んだL agrange粒子付Euler型スキームを提案・開発 する.この方法は，格子上に自由表面粒子とSPH粒子という 2種類のL agrange粒子を複数配置することによって，格子解 像以下の移動境界面を高精度に追跡するとともに, 密度関数 
の移流誤差を修正する点に大きな特徴を有している.これに よって, Euler型解法とL agrange型解法のメリットを生かしつ つ, 固気液界面の数值拡散や圧力解の不安定性を抑制する可 能性がある. 本論では, 波浪衝撃圧による厚肉・薄肉弾性構 造体の大変形問題への適用を念頭に, 人工応力項の導入, L agrange粒子の再分配の高効率化, 固体流体相互作用項の取 り扱い, 密度関数の補正方法等, 様々な改良を加え, 衝撃圧 が作用する諸問題のみならず, 波浪衝撃圧による流力弾性・ 振動問題に本手法を適用し，その有用性を検証する。

\section{2. 数值計算法}

流体構造連成問題を計算力学的に取り扱うには, Lagrange 型解法となる構造体の解析法と Euler 型解法となる流体の解 析法をどのように融合させるかがポイントとなる.本章では， まず始めに質量保存と界面の追跡精度を向上させるために 配置された L agrange 粒子の定義と特徵, その役割について 述べる. 次いで，本論で最も重要となる密度関数の修正法， 粒子配置・再配分の効率化, 流体構造相互作用の取り扱いに ついて記述する。

\subsection{Lagrange 粒子付 Euler 型スキーム}

\subsubsection{Lagrange 粒子の定義とその特徵}

著者らが開発した L agranger 粒子付 Euler 型スキームでは, 固気液 3 相の移動境界面を高精度に追跡するために, 密度関 数 $\phi_{1} \quad\left(0 \leq \phi_{1} \leq 1, \quad I=1\right.$ : 気相, I = 2 : 液相, I = 3 : 固相 $)$ の移流計算だけでなく, これとは別に L agrange 粒子（自由 表面粒子とSPH 粒子）を新たに配置する。これら L agrange 粒子によって, 格子サイズ以下の界面情報を保持するととも に, 粒子配置から密度関数 $\phi_{1}$ を修正することで, 固気液 3 相の移動境界面の追跡精度を大幅に高めることができる.

格子・粒子系および物理量の定義点については, Fig.1に 示すようにスタッガード格子に従う。つまり, 速度はセル境 界に定義するとともに, 圧力, 密度, 粘性係数はセル中心に 定義する. その一方で，密度関数 $\phi_{1}$ は格子の角点に定義す る.さらに, Lagrange 粒子位置において密度関数 $\phi_{\mathrm{P}}$ を新た に定義しここの值は粒子の移流とともに保持され続けるもの とする.

Fig.2 に L agrange 粒子付 Euler 型スキームの概念図を示す. 図より, 計算領域を直交格子で分割するとともに, 自由表面 粒子 ( ○印) と SPH 粒子（＼cjkstart印）を分布させる。本研究で は, 固相の弾性応答・大変形・振動を高精度で捉えるために SPH 粒子を配置する。 つまり, 固相領域については, 粒子 法の一種である SPH 法を適用し, 格子サイズ以下の弾性応 答 - 大変形 - 振動を解析し, その SPH 粒子位置の分布や速

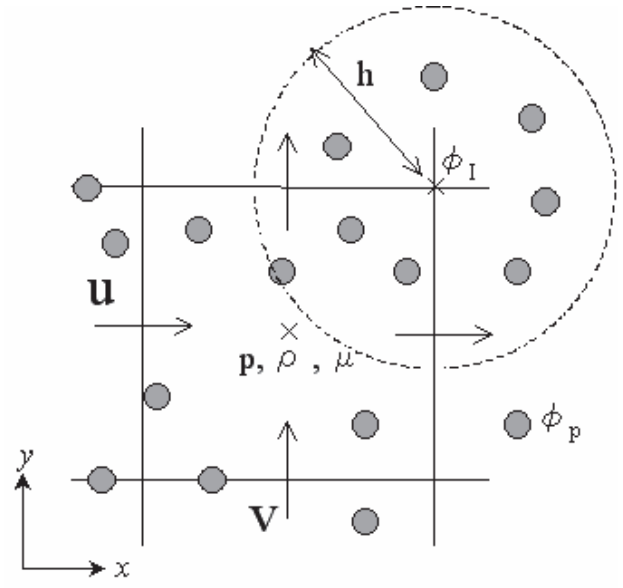

Fig.1 Definition of physical values on a grid and Lagrangian particles

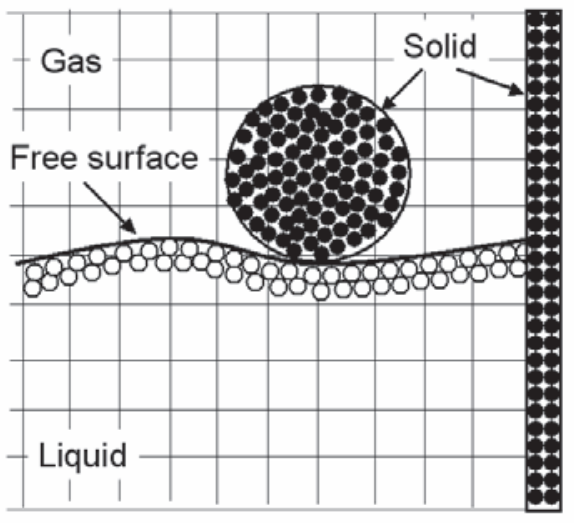

Fig.2 Grid arrangement and particle distribution

( : SPH particles, O : Free surface particles )

度にしたがって, 格子で定義された密度関数 $\phi_{I} \quad(I=3$ : 固相 $)$ やセル界面の速度を修正する。一方，自由表面粒子は，気液 相の境界面を高精度で追跡することを目的として配置され るものである。この粒子は質量を持たず, 密度関数の勾配が 急激に変化するところ, すなわち自由表面付近にのみ集中的 に配置される。なお，界面の両サイドに粒子を分布させる Particle Level Set 法 ${ }^{15)}$ と比較して, 本手法は界面の片側サイ ドにのみ約半分の粒子を配置すれば良いことに加え, 粒子の 除去・再配置プロセス時の粒子探索による計算負荷が少ない という利点を有している。この自由表面粒子は, 格子サイズ 以下の気液界面情報を保持しているため, これらの分布から， 格子で定義された気相と液相の密度関数 $\phi_{I} \quad(I=1$ : 気相, $\mathrm{I}=2$ : 液相）を適宜修正する。この時，1 セルあたり 4 個（2 次元の場合）または 8 個（3 次元の場合）程度になるように 粒子を配置する. なお, 粒子半径 $r_{p}$ は格子サイズの $1 / 4$ 程度 とし，計算中において常に一定としており，粒子径を変化さ せる Particle Level Set 法 ${ }^{15)}$ とは大きく異なっている．この自 由表面粒子によって, 液相体積誤差が $0.1 \%$ 以下になるため, 保存性は極めて高いことを確認している 12), 14),16). 


\subsubsection{Lagrange 粒子の速度および時間発展}

気液界面に配置された自由表面粒子は, 次式の時間発展方 程式によって追跡がなされる。

$$
\frac{d \vec{x}_{p}}{d t}=\vec{u}\left(\vec{x}_{p}\right)
$$

ここで， $\vec{x}_{p}$ は, 粒子位置を示し, $\vec{u}\left(\vec{x}_{p}\right)$ はその粒子位置で の粒子速度を表している. 本研究では, 4 次精度 Runge-Kutta 法によって式(1)を解くことにする。

一方, 固相領域に配置された SPH 粒子は, 後述する固体 の運動方程式をSPH 法によって解き, 個々の粒子の移動速 度を求める. また, この粒子速度は, 格子のセル境界で定義 された速度場へ内挿補間することで, 格子に定義された速度 を修正する.この際，1つの格子内に存在する粒子数も考慮 し速度修正する。

\subsection{3 自由表面粒子の再配置}

本手法では, 自由表面の滑らかさおよび複雑さに合わせて, L agrange粒子の追加・削減を行うと同時に, それらの再配置 を行い, 計算の効率化・安定化と自由表面の追跡精度の向上 を図っている。ここでは, その粒子再配置アルゴリズムにつ いて説明する. 自由表面からの距離を認識するための指標と して, 距離関数 $\psi(x, y, z)(-\infty<\psi<+\infty)$ を新たに定義する. 境界面において距離関数 $\psi=0$ と設定し，これを基準として 計算空間全体で距離関数 $\psi(x, y, z)$ を求める. 次いで, 界面 からあるバンド幅 $\alpha$ 以内で, かつ, 密度関数 $\phi$ 至ある值以 上（例えば，0.5以上）となる領域の格子に対してのみ粒子 を配置する，これらの概念図をFig.3に示す，ここでは，粒 子を境界面に引き寄せるために, Enrightら ${ }^{15)}$ が提案した下 式を用いて新しい粒子位置 $\vec{x}_{p, n e w}$ を求めることにする.

$$
\vec{x}_{\text {p.new }}=\vec{x}_{p, \text { old }}+\lambda\left(\psi \text { goal }-\psi\left(\vec{x}_{p}\right)\right) \vec{N}\left(\vec{x}_{p}\right)
$$

ここで， $\lambda$ は 1 に設定した. また, $\psi\left(\vec{x}_{p}\right)$ は粒子位置 $\vec{x}_{p}$ に おける距離関数を示している. ここで $\vec{N}\left(\vec{x}_{p}\right)$ と $\psi_{\text {goal }}$ につい ては文献 ${ }^{15), 16)}$ と同様に以下のように定義した。

$$
\overrightarrow{\mathrm{N}}=\frac{\nabla \psi}{|\nabla \psi|}
$$

$$
\psi_{\text {goal }}=\left\{\begin{array}{ccc}
b_{\max } & \left(\left|\psi\left(\vec{x}_{p}\right)\right|>b_{\max },\right. & \left.\psi\left(\vec{x}_{p}\right)>0\right) \\
-b_{\max } & \left(\left|\psi\left(\vec{x}_{p}\right)\right|>b_{\max },\right. & \left.\psi\left(\vec{x}_{p}\right)<0\right) \\
b_{\min } & \left(\left|\psi\left(\vec{x}_{p}\right)\right|<b_{\min },\right. & \left.\psi\left(\vec{x}_{p}\right)>0\right) \\
-b_{\min } & \left(\left|\psi\left(\vec{x}_{p}\right)\right|<b_{\min },\right. & \left.\psi\left(\vec{x}_{p}\right)<0\right)
\end{array}\right.
$$

ここで， $b_{\text {max }}$ および $b_{\min }$ は以下のように決定される.なお， 本論文では $\alpha$ は2程度， $\beta$ は0.1〜0.75程度に設定することと した.

$$
\left\{\begin{array}{l}
b_{\max }=\alpha \max (d x, d y, d z) \\
b_{\min }=\beta \max (d x, d y, d z)
\end{array}\right.
$$

さらに, 急激な自由表面変形の追跡に対しては, 以下の条

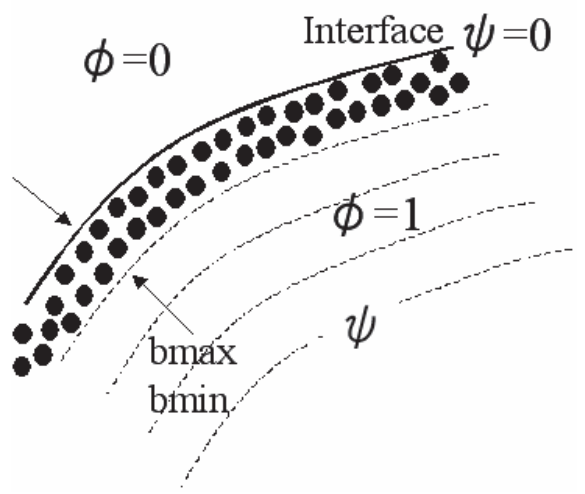

Fig.3 Illustration of redistribution process of free surface particles near the free surface

件を満足する格子の中心に1個の粒子を配置することとした.

$$
\alpha<\psi(\mathrm{x}, \mathrm{y}, \mathrm{z})<\gamma
$$

ここで, $\gamma$ は格子サイズの4～6倍程度の值を取り得るもので ある. 最後に, $\psi\left(\vec{x}_{p}\right)<0$ となる粒子を排除することで, 再 配置アルゴリズムは終了する. なお $\alpha, \beta$ および $\gamma$ は，計 算対象となる流体現象に依存するパラメータであり経験的 に設定しているが, 格子サイズや時間刻みなどとの関連付け を行って決定付けることも可能である. 以上のような粒子の 再配置アルゴリズムは, 計算負荷の増大要因となるため, 対 象とする流体現象にあわせて適当な時間間隔で行うことに する.

\subsection{4 格子の密度関数 $\phi \mid$ の修正方法}

格子で定義された固気液3相の密度関数 $\phi_{1} \quad(I=1$ : 気相, I = 2 : 液相， I = 3 : 固相）は, 時々刻々，移流誤差が残った り, 蓄積したりするため, 流体力および界面追跡の大幅な精 度低下を招くことがある，そこで，本研究では，SPH法など で用いられるK ernel関数を用いて, 密度関数 $\phi$, 修正する ことにする. SPH法では, 粒子 i の位置での物理量 $\phi_{1}$ は, その周囲の粒子 $\mathrm{N}$ 個の物理量の足し合わせで以下のように 定義される.

$$
\phi_{1}=\sum_{j=1}^{N} m_{j} \frac{\phi_{j}}{\rho_{j}} W_{i j}
$$

この式は，2次元の場合，影響半径 h の円内（Fig.1参照） にある $\mathrm{N}$ 個の粒子の持つ物理量を重み関数Wを用いて評価 点へ内挿することを示している。本論文では，式(7)の考え 方に基づき, 修正後の格子の密度関数 $\phi_{\mid}^{\prime}$ は, 影響半径 $\mathrm{h}$ 内 に含まれる粒子の密度関数 $\phi_{\mathrm{p}}$ を用いて, 下式で評価する.

$$
\phi_{1}^{\prime}=\max \left(\phi_{1}, \sum_{j=1}^{N} \phi_{p} \frac{m_{p}}{\rho_{p}} w_{p}\left(\left|x_{g}-x_{p}\right|, h\right)\right)
$$

ここで, $\mathrm{m}_{\mathrm{p}} / \rho_{\mathrm{p}}$ は粒子体積 $\mathrm{V}_{\mathrm{p}}$ で半径 $\mathrm{r}_{\mathrm{p}}$ を用いて求められ る. $W_{p}$ は Kernel 関数であり 3 次スプライン関数を用いる. また， $x_{g}$ および $x_{p}$ は，格子および粒子の位置べクトルを表 
す。なお, 本論文では, 影響範囲 $\mathrm{h}$ は, 格子サイズの 2 倍と した.

\section{2 固相領域の支配方程式とその解法}

固相の方程式は，以下の連続の式と運動方程式である.

$$
\begin{gathered}
\frac{\mathrm{D} \rho}{\mathrm{dt}}+\rho \frac{\partial \mathrm{u}^{\mathrm{i}}}{\partial \mathrm{x}^{\mathrm{i}}}=0 \\
\frac{\mathrm{du}^{\mathrm{i}}}{\mathrm{dt}}=\frac{1}{\rho} \frac{\partial \sigma^{\mathrm{ij}}}{\partial \mathrm{x}^{\mathrm{j}}}+\mathrm{g}^{\mathrm{i}}+\mathrm{F}_{\text {fsi }}^{\mathrm{i}}
\end{gathered}
$$

ここで, $\rho$ は密度, $u^{i}$ は速度, $x^{j}$ は位置ベクトルの $\mathrm{j}$ 方向 成分, $\sigma^{\mathrm{ij}}$ は固体・流体の応力テンソル, $\mathrm{F}_{\mathrm{fsi}}$ は固体・流体 相互作用項である. 固体領域の計算をする場合, 式(10) に 示寸固体の応力テンソル $\sigma_{\mathrm{s}}^{\mathrm{ij}}$ は, 以下の通りである.

$$
\sigma_{\mathrm{s}}^{\mathrm{ij}}=-\mathrm{P} \delta^{\mathrm{ij}}+\mathrm{S}^{\mathrm{ij}}
$$

ここで, $S^{i j}$ は偏差応力成分, $P=-\sigma_{\mathrm{kk}} / 3$ である. 弾性体が 大変形する場合, 物体形状が時々刻々変化することを考慮に 入れた扱いが必要であり, 増分型構成式は, 以下のようにな る.

$$
\left\{d S^{i j}\right\}=\left[D^{e}\right]\left\{d \varepsilon^{i j}\right\}
$$

ここで， $D^{\mathrm{e}}$ は弾性マトリックス， $\mathrm{d} \varepsilon^{\mathrm{ij}}$ はひずみの時間増 分, $d S^{i j}$ は偏差応力の時間増分であり, 変形時の固相の回転 運動を考慮するために, 本研究では以下の Jaumann 速度を 用いる。

$$
\frac{\mathrm{d} \mathrm{S}^{\mathrm{ij}}}{\mathrm{dt}}=2 \mu\left(\dot{\varepsilon}^{\mathrm{ij}}-\frac{1}{3} \delta_{\mathrm{ij}} \dot{\varepsilon}^{\mathrm{ij}}\right)+\mathrm{S}^{\mathrm{ik}} \Omega^{\mathrm{jk}}+\Omega^{\mathrm{ik}} \mathrm{S}^{\mathrm{kj}}
$$

以上, 大変形解析を行うためのJaumann速度を用いると, 固 体の支配方程式(10)は，以下のようになる.

$$
\begin{aligned}
\frac{d u_{a}^{i}}{d t} & =\sum_{b} m_{b}\left(-\left(\frac{P_{a}}{\rho_{a}^{2}}+\frac{P_{b}}{\rho_{b}^{2}}\right) \delta^{i j}+\frac{S_{a}^{i j}}{\rho_{a}^{2}}+\frac{S_{b}^{i j}}{\rho_{b}^{2}}\right. \\
& \left.+\Pi_{a b} \delta^{i j}+R_{a b}^{i j} f^{n}\right) \frac{\partial W_{a b}}{\partial_{a} x^{j}}+g^{i}-\frac{F_{f s i}}{\rho_{a}}
\end{aligned}
$$

ここで, $\Pi_{a b}$ は人工粘性項, $R_{a b}^{i j} f^{n}$ は ray $5^{17)}$ の提案した人 工応力項を示し, 人工応力係数 $\varepsilon$ が含まれた関数である. 例 えば，2次元の場合，

$$
\bar{R}_{a}^{x x}=\left\{\begin{array}{cccc}
-\varepsilon \frac{\bar{\sigma}_{a}^{x x}}{\rho_{a}^{2}}, & \text { if } \quad \bar{\sigma}_{a}^{\mathrm{xx}}>0 & \text { (Tension) } \\
0, & \text { if } \quad \bar{\sigma}_{\mathrm{a}}^{\mathrm{xx}} \leq 0 & \text { (Compression) }
\end{array}\right.
$$

となる.ここで, $\varepsilon=0$ の時は, 人工忘力を考慮しないこと に相当する. 詳しくは文献 ${ }^{17)}$ 参照されたい.

以上まとめると，式(13)の偏差応力成分 $S^{i j}$ の時間発展は, 式(12)に示す時間増分量を時間積分することにより，時々 刻々求めることができる。ささらに，その偏差応力 $\mathrm{S}^{\alpha \beta}$ と流 体力 P（後述の式(23)から求められる）を式(11)に代入寸れ
ば，時々刻々の応力 $\sigma_{\mathrm{s}}^{\mathrm{ij}}$ を求めることが可能となり，最終的 に式(10)の粒子速度 $u_{i}^{n+1}$, さらには次時刻の粒子位置が得ら れる. 次に, ポアソン方程式から液相と固相の圧力を計算す る. 求めた圧力と各粒子の速度から運動方程式によって加速 度を計算する. 運動方程式を計算する際, 液相については圧 力項と粘性項, 固体については圧力項と偏差忘力の項に分け て計算を行う。

また，式(14)にある相互作用項 $\mathrm{F}_{\mathrm{fsi}}$ は，以下の通り，固気 液 3 相の圧力（格子で定義される圧力として後述の式(23)か ら求められる。）を，固体粒子上の圧力八内挿補間し，以下 の式により加速度を算出することで評価することが出来る.

$$
\mathrm{F}_{\mathrm{fsi}}\left(\boldsymbol{r}_{\mathrm{a}}\right)=-\frac{1}{\rho\left(r_{\mathrm{a}}\right)} \sum_{\mathrm{b}} \mathrm{m}_{\mathrm{b}} \frac{\mathrm{P}\left(\boldsymbol{r}_{\mathrm{b}}\right)}{\rho\left(\boldsymbol{r}_{\mathrm{b}}\right)} \nabla_{\mathrm{a}} \cdot \mathrm{W}\left(\boldsymbol{r}_{\mathrm{a}}-\boldsymbol{r}_{\mathrm{b}}, \mathrm{h}\right)
$$

偏差応力の項はそれぞれ固相粒子のみの足し合わせで評 価する. 求めた值から, 各粒子の密度, 速度, 位置などの物 理量を更新する.

\section{3 流体領域の支配方程式とその解法}

著者らの既往の研究 ${ }^{14)}$ において, 圧縮性流体と非圧縮性 流体の支配方程式に基づく数值実験を行った結果, 本論文で 取り扱う条件下であれば, 直立壁に作用する衝撃砕波圧の最 大值およびその振動挙動に大局的な差異は生じないことを 確認している，そこで，本論文においても，支配方程式は以 下に示寸質量保存式，非压縮粘性 N avier-Stokes 方程式， I 相 の密度関数 $\phi_{1}\left(0 \leq \phi_{1} \leq 1\right)$ の移流方程式とした.

$$
\begin{aligned}
& \frac{\partial u_{i}}{\partial x_{i}}=0 \\
& \frac{\partial u_{i}}{\partial t}+u_{j} \frac{\partial u_{i}}{\partial x_{j}}=-\frac{1}{\rho} \frac{\partial P}{\partial x_{i}}+\frac{\mu}{\rho} \frac{\partial^{2} u_{i}}{\partial x_{j} \partial x_{j}}+g_{i}+F_{f s i} \\
& \frac{\partial \phi_{l}}{\partial t}+u_{j} \frac{\partial \phi_{l}}{\partial x_{j}}=0
\end{aligned}
$$

ここで， $I$ 相とは，気相 $(I=1)$ ，液相（I=2），固相（I =3）を意味し， $g_{\mathrm{i}}$ は重力加速度項， $\mathrm{F}_{\mathrm{fsi}}$ は相互作用項であ り， $\phi_{\mid}$は $0 \leq \phi_{\mid} \leq 1$ および以下の条件を満足する.

$$
\phi_{\mid}= \begin{cases}1 & \text { occupied } \\ 0 & \text { otherwise }\end{cases}
$$

なお, 固相の密度関数 $\phi_{\mid} \quad(I=3)$ は, 後述する SPH 粒子に よって，その界面情報の修正がなされる.

これらの支配方程式の解法には time splitting 法を用いる. まず始めに, M 型 CIP 法 ${ }^{18)}$ を用いた移流相の計算の後, 以 下のポアソン方程式から $n+1$ 時刻目の圧力を計算し，その 後，非移流相の計算を行う.

$$
\nabla \cdot\left(\frac{\nabla \mathrm{P}^{\mathrm{n}+1}}{\rho^{*}}\right)=\frac{\nabla \cdot \mathrm{u}^{*}}{\Delta \mathrm{t}}
$$


ここで，*は移流後の計算值を示す.なお，このポアソン方 程式を解いた場合, 固相領域においても同時に圧力解が求め られる.この圧力值を前述の固体変形解析において利用する. 次いで, 得られた流速場を基に, 密度関数の移流計算を行 う。なお, 流体の物性である密度 $\rho$ および粘性係数 $\mu$ は, 密度関数 $\phi_{1}$ を用いて, 下式によって求める.

$$
\begin{aligned}
& \rho=\sum_{\mathrm{I}=1}^{3} \rho_{\mathrm{I}} \phi_{\mathrm{I}} \\
& \mu=\sum_{\mathrm{I}=1}^{3} \mu_{\mathrm{I}} \phi_{\mathrm{I}}
\end{aligned}
$$

なお，固体一流体連成問題を取り扱うために，流体領域と 固体領域の時間刻みを変える必要がある。ここでは, 下式に 示すように, 流体ルーチン 1 回に付き, 固体ルーチンは N 回ステップ行うことにした。

$$
\Delta \mathrm{t}_{\mathrm{f}}=\mathrm{N} \times \Delta \mathrm{t}_{\mathrm{s}}
$$

ここで， $\Delta \mathrm{t}_{\mathrm{f}}$ は流体ルーチンの時間刻み， $\Delta \mathrm{t}_{\mathrm{s}}$ は固体ルーチ ンの時間刻みを表す。

\section{3. 数値計算結果}

水しぶきを伴う流体と構造物の動的応答解析を行う場合， 外力となる流体力（衝撃圧を含む）を正確かつ安定に計算す る必要がある. そこで, まず始めに剛体と流体の相互作用問 題に適用し，剛体に作用する衝撃圧の精度検証を行う. 次い で, 弾性体と流体の相互作用問題に適用し, 本手法の有用性 を検証する。

\section{1 ダム崩壊と剛体の相互作用問題への適用と精度検証}

本節では，幅 $3.22 \mathrm{~m} \times$ 奥行き $1.0 \mathrm{~m} \times$ 高さ $1.0 \mathrm{~m} の$ 計算領域内 に，右側領域より高さ $0.55 \mathrm{~m}$ の水柱および剛体 $(0.15 \mathrm{~m} \times$ $0.15 \mathrm{~m} \times 0.4 \mathrm{~m})$ を固定し(Fig.4)，剛体全面及び上面に作用す る衝撃圧について, Kleefsman $5^{19)}$ の実験結果と比較する. 格子サイズは $14 \mathrm{~mm} \times 20 \mathrm{~mm} \times 15 \mathrm{~mm}$ とし，時間刻みを $1.0 \times$

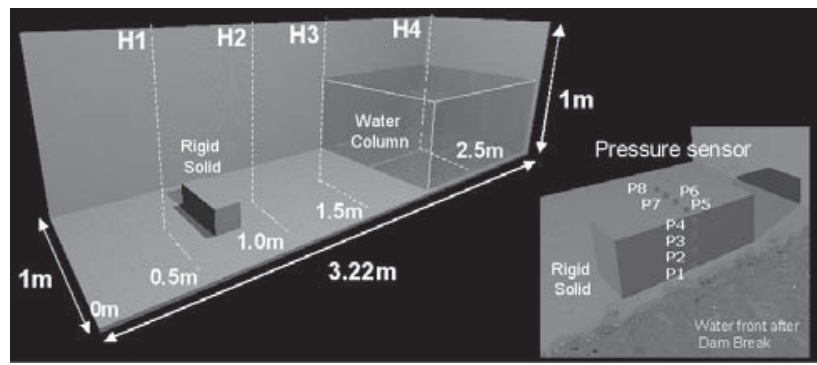

Fig.4 Initial condition of a dam breaking acting on a rigid solid $(H$ : Sensor location of the water elevation, $P$ : Location of the pressure sensor on the face of the rigid solid (Right figure) ).
$10^{-4} \mathrm{~s}$ とた。粒子密度は液相 $1000 \mathrm{~kg} / \mathrm{m}^{3}$, 気相 $1.25 \mathrm{~kg} / \mathrm{m}^{3}$, 固相（剛体） $7000 \mathrm{~kg} / \mathrm{m}^{3}$ とした。なお，剛体領域は約 1.7 万 個のSPH粒子（半径3.5mm）で構成するとともに，気液界面 付近には約27万個の自由表面粒子（半径3.5mm）が配置され ている.

Fig.5 は剛体前面の測点 P1，P3および上面の測点P7 に おける圧力変動の時系列変化についてKleefsmanら ${ }^{19)} の$ 結果 と比較したものである。なお，本数值計算結果は，剛体を SPH粒子で構成しているので, 剛体表面に配置された粒子に 作用する圧力值を示している。また，Fig.6はダム崩壊後の 水面挙動を示したものである.

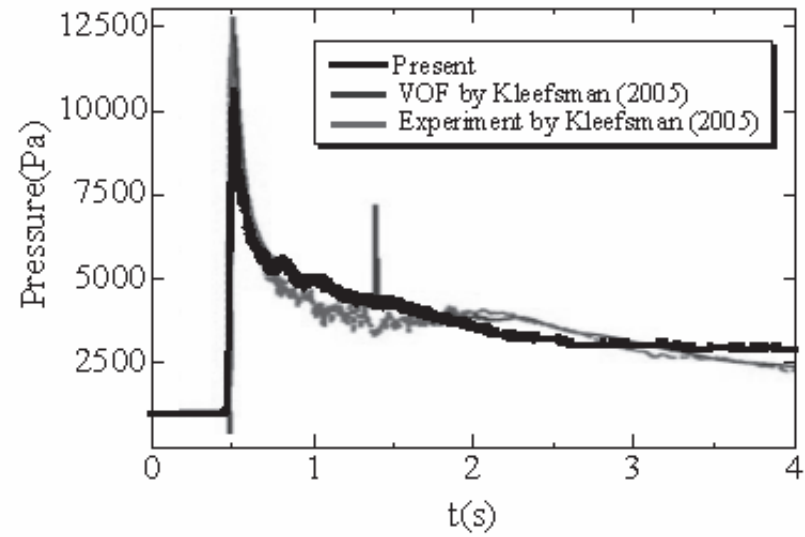

(a) Position P1

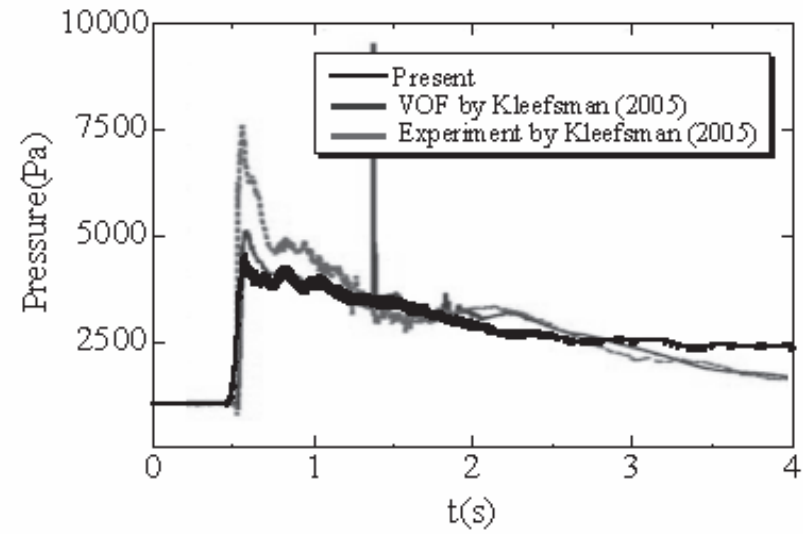

(b) Position P3

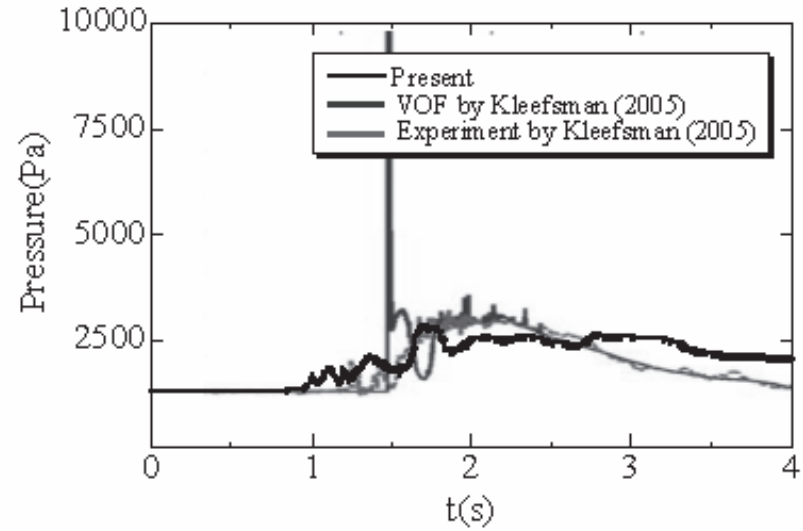

(c) Position P7

Fig.5 Time histories of impact pressure acting on the rigid solid 


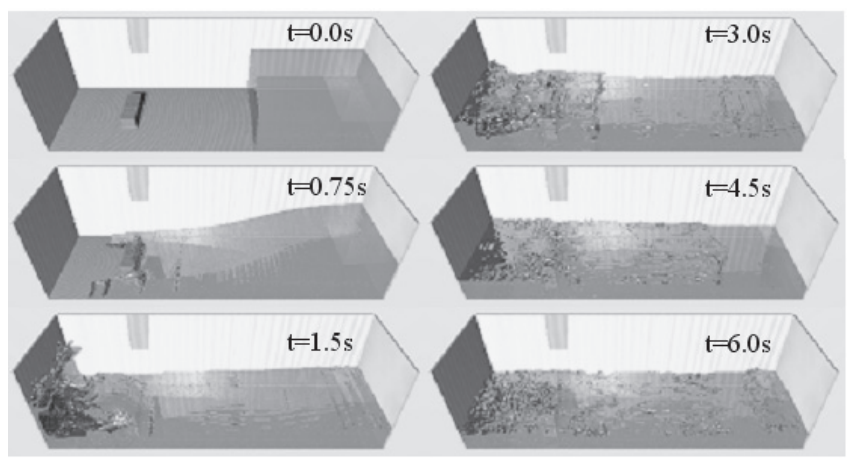

Fig.6 Free surface deformation with splashing after dam collapsing in 3D (Purple : rigid solid)

これらの図から, 本数值計算結果の圧力傾向は, いずれの 測点も概小一致した結果を得ている. しかしながら, 水塊の 打ち上げが激しい測点3の圧力ピーク值がやや過小評価とな っている点（時刻0.6〜0.75s付近）, 空気巻き込みを伴う上 面測点7の圧力の立ち上がりがわずかにズレてしまう点（時 刻1.0 1.5s付近），左壁から反射した波の伝播による圧力低 下傾向がやや過大となっている点 ( $\mathrm{t}=3 \mathrm{~s}$ 以降) について, 問 題を残す結果となった. これは, 非常に激しいスプラッシュ 現象や種々のスケールの封入気泡を計算するには, さらなる モデル改良が必要であることを意味しており, 今後の課題と なろう。

\section{2 剛体壁に作用する衝撃圧問題への適用と精度検証}

本節では，砕波後の空気巻き込みを伴う衝撃圧（B agnold 型, Fig.7参照) と砕波時の空気巻き込みのない場合 (W agner 型）の両者について精度検証することにする. 同一条件下の 実験結果 ${ }^{20)}$ と比較するため, 直立壁の位置 $\delta_{\mathrm{x}}$ は, 砕波点を 基準として， $\delta_{\mathrm{x}} / \mathrm{h}_{1}=0.0$ 及び1.13（ $\mathrm{h}_{1}$ : 水深）とした。 また， 入射波の波高水深比は $\mathrm{H}_{1} / h_{1}=0.473$ ある. なお，格子サ

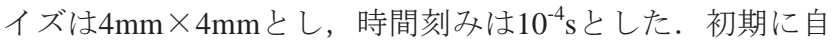
由表面付近に配置される自由表面粒子は約5万個とした。一 方, 右側境界に設置された直立壁は, 約 2.1 万個のSPH粒子 で構成することとした. なお, 自由表面および直立壁に配置 する粒子の半径は，いずれも格子サイズの4分の1 ( $1 \mathrm{~mm})$ とし，1格子当たり4個程度配置することとした。

Fig.8およびFig.9は，それぞれ砕波水塊の衝突時に空気巻 き込みのある場合（Wagner型）と空気巻き込みのない場合 (Bagnold型) の両ケースについて, 衝撃砕波圧の時系列変 化を比較検証したものである.いずれのケースも波圧のピー ク值およびその変動傾向は概ね良い一致を示しており, 両夕 イプの衝撃圧ともに, 本手法は良い精度で計算可能であるこ とが分かる. しかしながら, 封入空気塊による振動型圧力波 形の傾向について見ると, 周期については, 第1周期ピーク 時刻 0.028 , 第2周期ピーク時 0.038 までは概ね一致しているが,

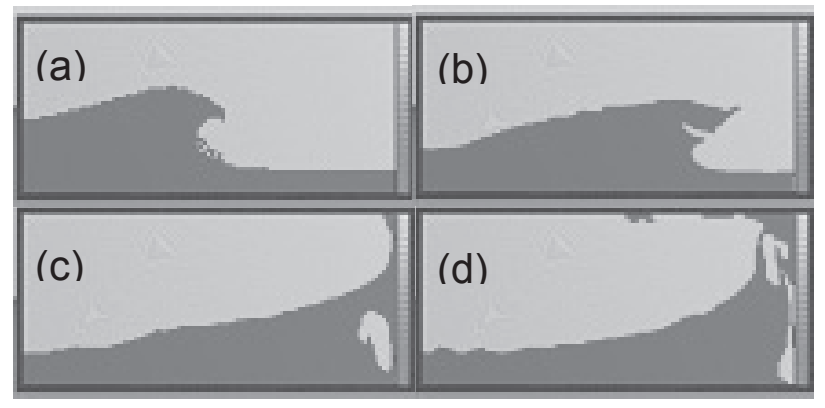

Fig.7 Wave breaking phenomena acting on the rigid wall with entrained air (Bagnold type). The vertical wall consists of SPH particles colored by purple.

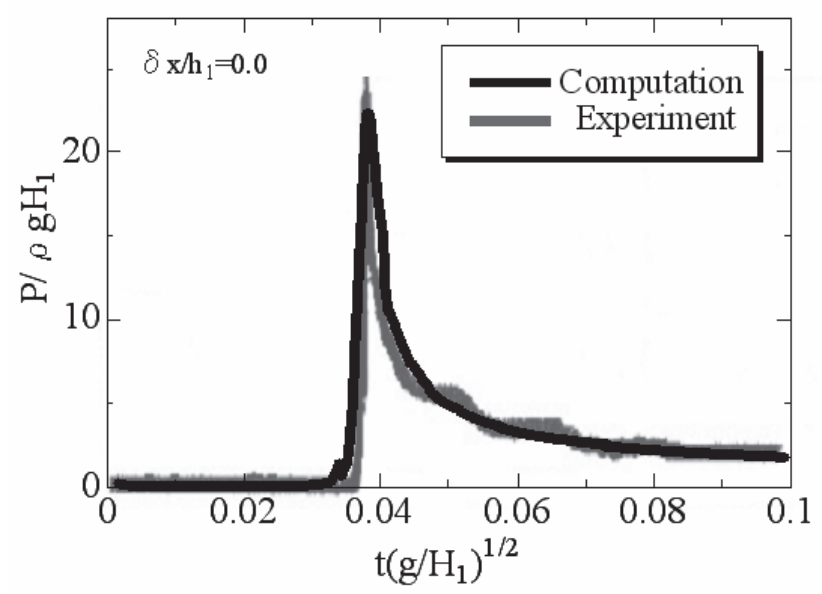

Fig.8 Time history of impact pressure without entrained air (Wagner type)

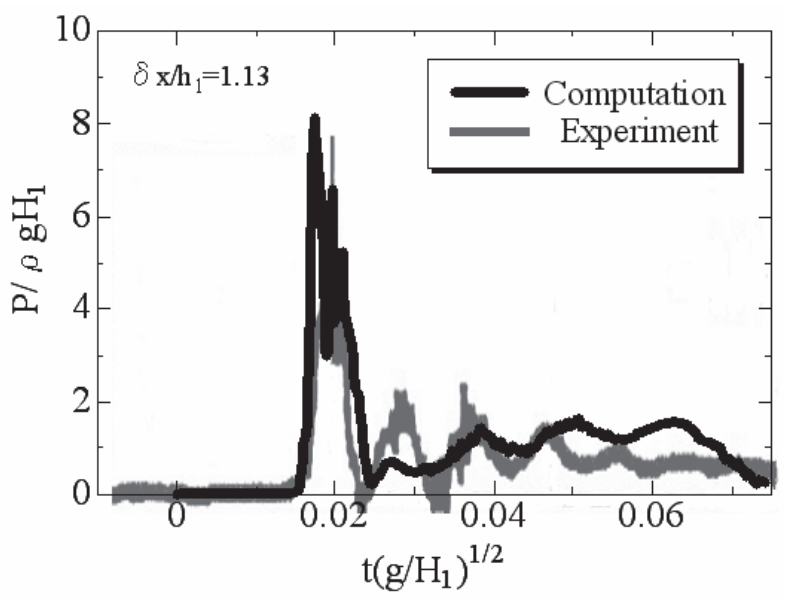

Fig.9 Time history of impact pressure with entrained air (Bagnold type)

その後の第3周期ピーク時刻 0.048 , 第4周期ピーク時刻 0.055 については周期のズレが出始める。この理由としては, 封入 空気や打ち上げ・落下水塊の挙動が, 定量的には一致しない ことによるものと考えられ, 格子スケール以下の微小気泡の 数理モデル化とその導入が不可欠と言える.

\section{3 弾性体と流体の相互作用問題への適用と精度検証}

本節では，水柱崩壊後，ゴム壁に流体力が作用し，ゴム壁 


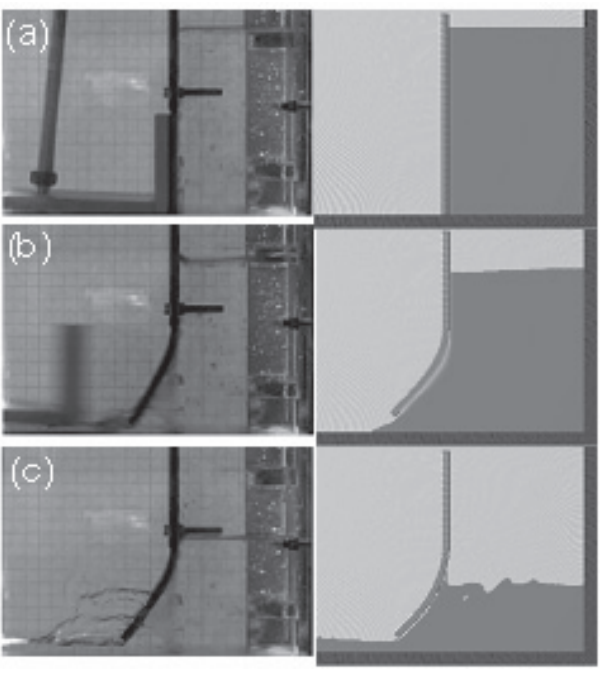

Fig.10 Comparison of elastic wall deformation and water elevation (L eft : Experiment ${ }^{21)}$, Right : Present)

が変形して, 水塊が飛び出していく現象 ${ }^{21)}$ を検証する. 幅 $A=$ $10 \mathrm{~cm}$, 高さ $\mathrm{H}=14 \mathrm{~cm}$, 奥行き $\mathrm{B}=10 \mathrm{~cm}$ の水柱前面前脚 部に, 高さ $L=7.9 \mathrm{~cm}$, 厚さ $s=5 \mathrm{~mm}$ のゴム材料の直立弾 性壁を設ける。このゴム壁の上端はクランプで固定され，下 端は自由端となっている。 ゴム壁の材料特性は, 密度 $\rho=$ $1100 \mathrm{~kg} / \mathrm{cm}^{3}$, ヤング係数 $\mathrm{E}=12 \mathrm{Mpa}$, ポアソン比 $v=0.4$ で ある。なお, 気液相の密度比 800 , 粘性比50 として実流体場 と同様とした。格子サイズは $1.25 \mathrm{~mm}$ とし，初期に自由表 面に配置される粒子（半径0.31mm）は約1万個であり，1 格 子当たり 4 個とした。一方, $5 \mathrm{~mm}$ 厚の薄いゴム壁は, わず か 4 メッシュで表現され, 約 2000 個のSPH粒子 (半径0.31 $\mathrm{mm}$ ）で構成されている。 なお， 2.2 節で説明した人工忘 力係数 $\varepsilon$ は, パラメータ分析の結果, 0.7 と設定した. Fig.10 は，本手法の計算結果（3相の密度関数分布）および実験結 果 ${ }^{21)}$ を比較したものである. 水柱が崩壊するとともに自由端 であるゴム下端から水塊が飛び出し, ゴム壁が大変形してい く様子が再現されており, 実験結果と概ね良い一致を示して いる事が分かる．特に，非常に薄い板厚 $5 \mathrm{~mm}$ のゴムの曲げ 変形に対して, 固相の密度関数 $\phi_{1} \quad(I=3)$ は数值拡散を生 じることなく, 弾性体の境界面をクリアーに捕捉している. このことは, 式(8)によってSPH粒子が固相の密度関数エラー を上手く修正していることを意味している.

次いで，このゴム壁の変形を定量的に検証するため, ゴム 壁下端の水平および鉛直変位を実験結果と比較することに した（Fig.11）。図より，水柱崩壊による流体力の一番大き い $\mathrm{t}=0.15 \mathrm{~s}$ 付近で水平・鉛直方向変位ともにピーク值に達 し, その後, 流体力とゴムの弾性力との力学バランスによっ て準定常状態となり,なだらかにゴム壁の変位が小さくなっ ていくことが分かる.このような傾向は, 実験結果において も見られ, ゴム変形は非常に良い一致を示している事がわか

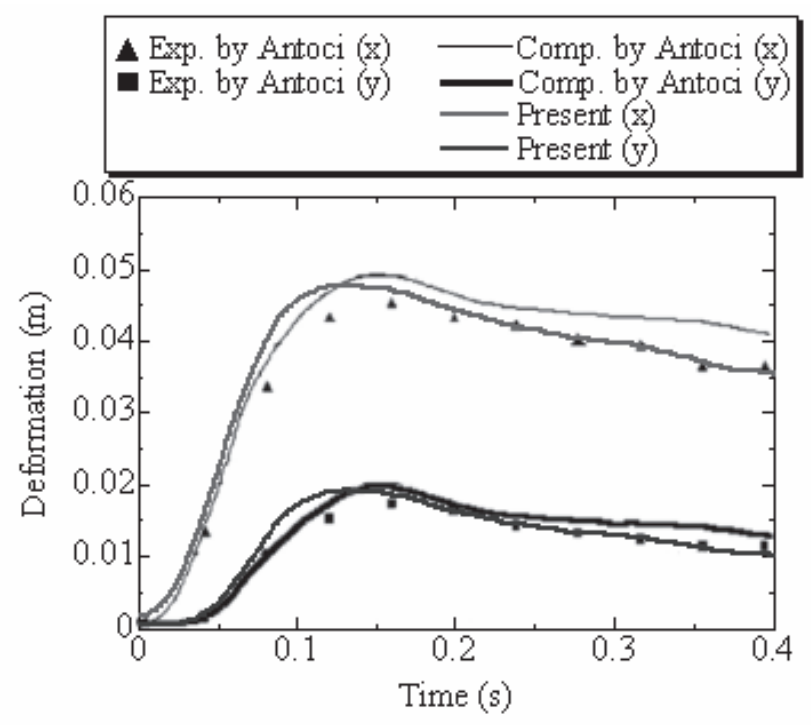

Fig.11 Comparison of time histories of horizontal and vertical deformation of the leading edge of the elastic wall.

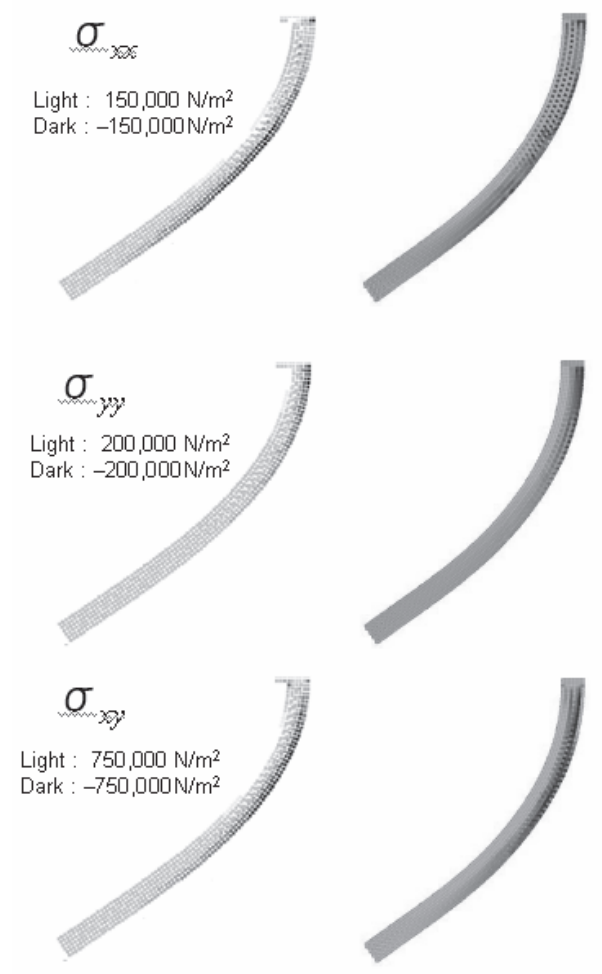

Fig.12 Comparison of internal stress field of the elastic wall. (Left : A ntoci's results ${ }^{21)}$, Right : Present results)

る。Fig.12は，SPH粒子で構成されたゴム壁内部の応力分布 について，ゴム壁の最大変位が生じる時刻でAntoci ら ${ }^{21)}$ の計 算結果と比較・検証したものである.引っ張りの曲げ領域で 応力が最大となる傾向や, 逆に, 圧縮の曲げ領域で応力が最 小となる傾向などは，定性的に捉えられていると言える。

\section{4 衝撃砕波圧による流力弾性問題への適用}

初期の波浪条件と壁面位置については陸田ら ${ }^{14)}$ と同様で 


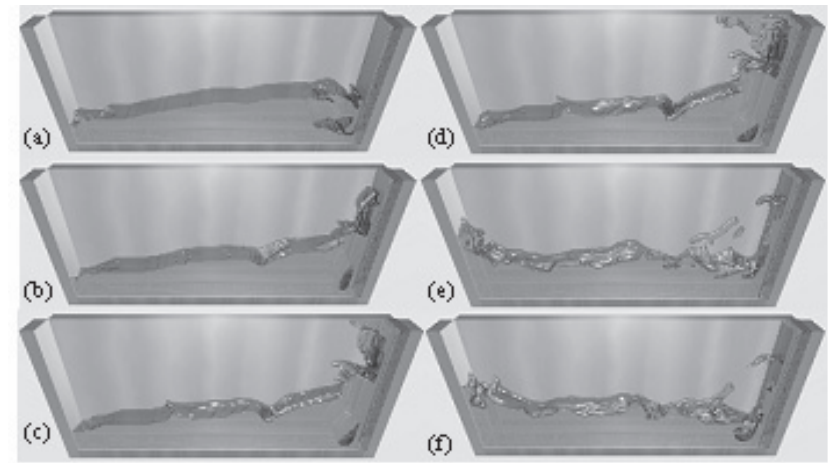

Fig.13 Wave breaking acting on a steel wall.

(a)
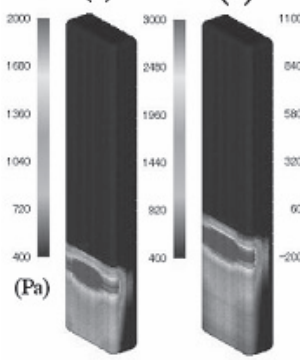

(c)

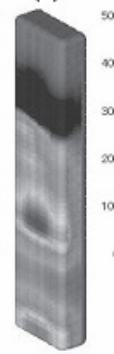

(d)

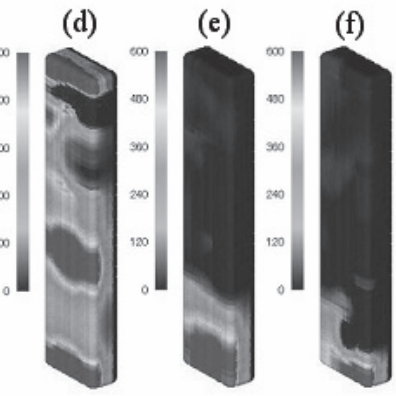

(f)

Fig.14 I mpact pressure field acting on a steel wall

あるが, 衝撃砕波圧の3次元特性も調べるために,ここでは, 奥行き一様の3次元問題として初期条件を設定した．鋼壁の 位置 $\delta_{\mathrm{x}}$ は，砕波点を基準として $\delta_{\mathrm{x}} / \mathrm{h}_{\mathrm{I}}=1.13\left(\mathrm{~h}_{\mathrm{I}}\right.$ : 水深 $)$ とした.また, 入射した孤立波の波高水深比は $\mathrm{H}_{1} / \mathrm{h}_{1}=0.473$ である。なお，格子サイズは $4 \mathrm{~mm} \times 4 \mathrm{~mm} \times 4 \mathrm{~mm}$ とし，時間 刻夕は $10^{-4} \mathrm{~s}$ とた。初期に自由表面付近に配置される自由表 面粒子は約5万個とした。一方, 右境界に設置された鋼壁 (肉 厚 $16 \mathrm{~mm}$ ，ヤング係数 $\mathrm{E}=210,000 \mathrm{M}$ pa，ポアソン比 $v=0.3$, 密度 $\rho=7,800 \mathrm{~kg} / \mathrm{m}^{3}$ ) は, 約 2.1 万個のSPH粒子で構成されて いる.なお，自由表面粒子および鋼壁を構成するSPH粒子の 半径は，いずれも格子サイズの4分の1 (1 mm) とし，1格子 当たり8個程度配置した。Fig.13は，鋼壁に砕波水塊が衝突 するシミュレーション結果である.なお,これらの図からは, 鋼壁が振動・応答・変形している様子は分からないが，実際 には変形・弾性振動を繰り返している.これに関しては, 後 節で詳細に調べることにする。鋼壁を構成しているSPH粒子 に作用する衝撃圧の時空間分布をFig.14に示す。ここで, Fig.14(a)〜 (f) はFig.13(a)〜 f) と同一時刻のものである. 図よ り，衝突時（Fig.14(a)(b)）および砕波後の打ち上げられた 水塊やスプラッシュが落下する過程 (Fig.14(e)) においては, 波峰方向（奥行き y 方向）にほぼ一様な衝撃圧分布を示し ていることが分かる、特に，ジェット水塊が直接衝突する鉛 直高さにおいて，このことは顕著である。一方，衝突後に空 気塊が取り込まれ押しつぶされていく過程 $(F i g .14(c)(d))$ においては，波峰方向（奥行きy方向）に3 次元性を有する 衝撃圧分布となっていることがわかる。これらのことから，

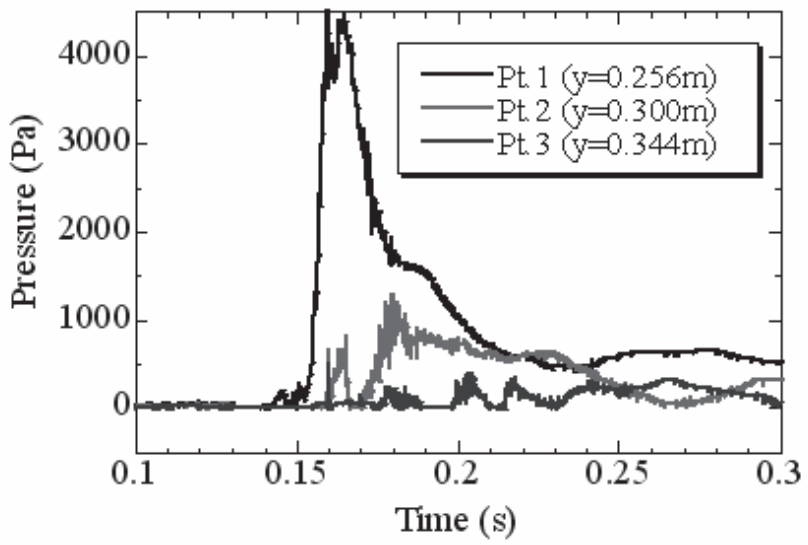

Fig.15 Time histories of internal pressure field at three points of a steel wall

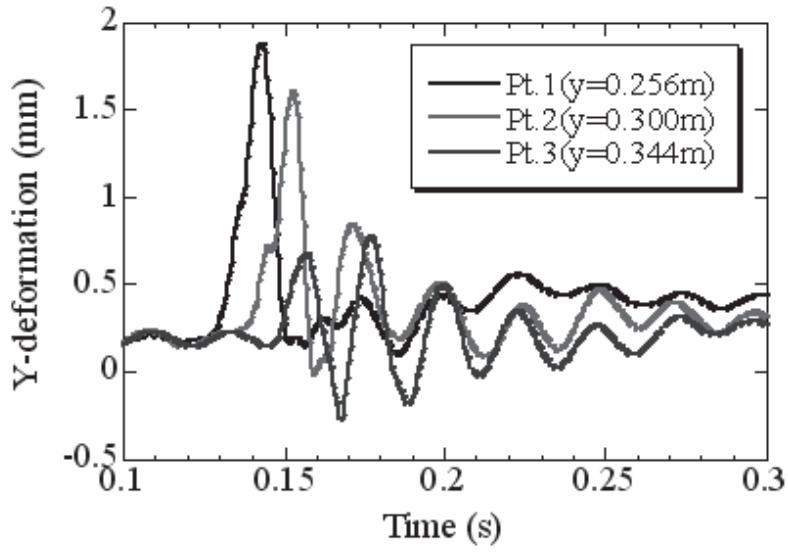

Fig.16 Time histories of deformation at three points of a streel wall

砕波後の水塊と直立壁面に封入された空気塊の3次元挙動に よって，壁面に作用する衝撃砕波圧も3次元的な空間分布を 示すことが分かる，さらに，その衝撃圧分布は，鋼壁の厚さ 方向にも変化していることから, 構造物内部にかかる応力・ ひずみ，弾性振動応答も3次元的になることが予想される.

Fig.15は，鋼壁内部の中央断面の測点Pt.1～Pt.3（下端から の距離はそれぞれ $\mathrm{y}=0.256, \mathrm{y}=0.300, \mathrm{y}=0.344 \mathrm{~m}$ ）に作用する 内部圧力の時系列変化を示している. なお，測点Pt.1は，砕 波ジェット水塊がダイレクトに衝突する鉛直高さ付近であ る.また，Fig.16は，同測点における $\mathrm{y}$ 方向の変位の時系列 変化を示したものである. 図から，ジェット水塊が作用する 測点Pt.1から上方測点 Pt.2 及び Pt.3 へと, 非常に短時間に 変位が伝播し, それらは減衰振動波形となっていることが分 かる。ささに，Fig.17は，同測点における内部応力の時系列 変化を示したものである. 測点Pt.1はジェット水塊が直接衝 突する高さ付近であるため，衝撃圧の圧力変動(Fig.15参照) に連動した応力波形となっている．しかしながら，他の測点 のそれは, 圧力や変位の振動波形と異なる傾向を示している. このことから, 今後, 構造体内部の応力・ひずみ・変形を実 験で計測し，詳細に検証を重ねていく必要があると言える. 


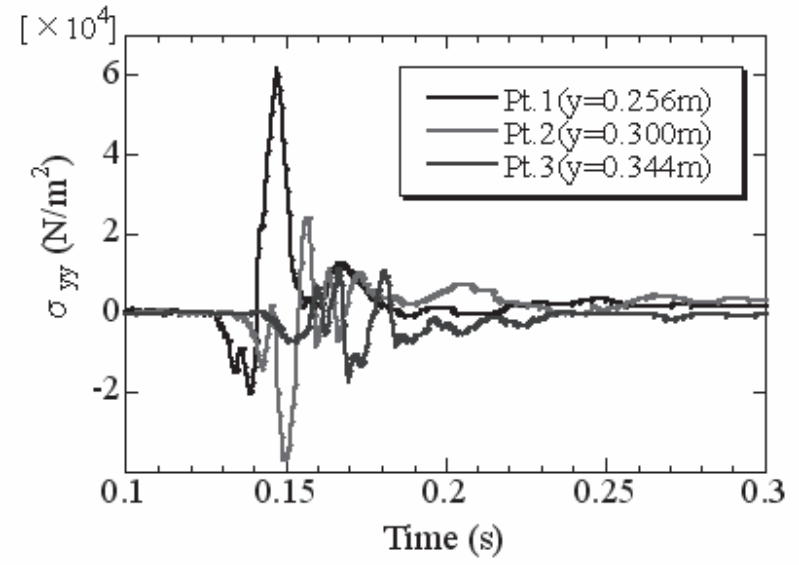

Fig.17 Time histories of internal stress $\sigma_{\mathrm{yy}}$ at three points of a steel wall.

\section{4. 結 論}

本論文では, 衝撃圧による固体流体連成問題に対する数值 計算法として, Lagrange粒子付Euler型スキームを提案・開発 した.また, 同手法を, 衝撃圧が作用する諸問題のみならず, 流力弾性・振動問題に適用した。 以下に主要な結論を示す.

1. 気液界面付近にの夕配置された自由表面粒子は, 格子 上に定義された密度関数の数值誤差を修正するととも に，気液界面をクリアーに追跡・維持する役割を果た しており，極めて有用であることが示された.

2. 衝撃圧が作用する3次元問題（剛体とダムの相互作用問 題, 波浪衝撃問題) において, 衝撃圧のピーク值およ び時系列変化は, 実験結果と良い一致を示すことを確 認した.

3. 流体力がゴム壁（弾性体）に作用する問題において, 曲げ変形, 応力分布を検証した結果, 実験・数值計算 結果と良い一致を示した。

4. 砕波時のジェット水塊による鋼壁の振動挙動, 衝撃圧 の減衰振動, 応力・ひずみ特性を概ね捉えることが可 能となった. しかしながら, 材料特性を変化させて, さらなる検証が必要と考えられる.

\section{参 考 文 献}

1) Faltinsen, O. M . : Hydroelastic slamming, Journal of M arine Science and Technology (2000) pp.49-65.

2) Korobkin, A., Gueret, R. and M alenica, S. : Hydroelastic coupling of beam finite element model with Wagner theory of water impact, Journal of Fluids and Structures, 22(2006), pp.493-504.

3)Hirt CW, Amsden AA, Cook JL : A rbitrary Lagrangian-Eulerian computing method for all flow speeds, J Comput Phys, 14(1974), pp.227-252.

4) Tezduyar TE, Behr M. : A new strategy for finite element computations involving moving boundaries and interfaces, Comput Methods Appl Mech Engrg, Vol. 94(1992), pp.339-351.

5) Peskin CS : The immersed boundary method, Acta Nuerica 2002, V ol.11, pp.479-517.

6) Changhong $\mathrm{Hu}$, Odd Faltinsen and Masashi Kashiwagi : 3-D N umerical Simulation of F reely M oving Floating Body by CIP Method,Proc. 15th International Offshore and Polar Engineering Conference,Vol. 4(2005), pp.674-679.

7) 李 光浩, 水谷法美 : Immerged Boundary 法による数值波 動水槽の構築とその応用に関する研究, 海岸工学論文集, 第 54 巻(2007), pp.821-825.

8) 牛島 省, 福谷 彰, 牧野 統師, 禰津家久: 3次元流体中 を運動する接触と変形を考慮した任意形状固体モデルの 数值解法, 応用力学論文集, Vol.10(2007), pp.139-146.

9) 近澤佳隆, 越塚誠一, 岡 芳明 : 粒子法による構造物の解 析手法の開発とその沿岸構造物への適用，海岸工学論文 集, 第 47 巻(2000), pp.41-45.

10）近澤佳隆, 越塚誠一, 岡 芳明: M PS 法を用いた液面と 構造物の大変形を伴うスロッシングの数值解析, 機械学会 論文集，B 編， 65 巻， 637 号(1999), pp.2954-2960.

11) 澤田有弘：重合 ALE メッシュによる流体・構造連成有 限要素解析に関寸る研究, 東京大学博士論文(2006), 135p.

12) 陸田秀実・伊澤亮・土井康明 : Particle CIP 法による高 精度な移動境界面の捕獲, 土木学会論文集, B 編, V ol.62, No.4 (2006), pp.376-387.

13)Gingold R.A., Monaghan J.J. : Smoothed particle hydrodynamics, theory and application to non-spherical stars, Mon. N ot. Roy. A str. Soc. V ol.181(1977), pp.375-389.

14) 陸田秀実・土井康明: 砕波による衝撃圧の直接推定と構 造物の動的解析, 土木学会論文集, B 編, V ol.62, N 0.3 (2006), pp.224-237.

15) Enright, D, R. Fedkiw, J. Ferziger, I. Mitchell : A hybrid particle level set method for improved interface capturing, J. Comput. Phys., 183(1) (2002), p.83-116.

16) 陸田秀実 : Particle CIP法による水面衝撃問題の数值解析, 応用力学論文集, V ol.10(2007), pp.121-130.

17) Gray, J. P., J. J. Monaghan and R. P. Swift : SPH elastic dynamics, Computer methods in Applied Mechanics and Engineering, 190(2001), pp.6641-6662.

18) $Y$ abe, T., H. M izoe, K. Takizawa, H. M oriki, Hyo-N am Im and $Y$. Ogata. : Higher-order schemes with CIP method and adaptive Soroban grid towards mesh-free scheme, J. Comput. Phys., 194(2004), pp.57-77.

19) Kleefsman, K. M. T., G. Fekken, A.E.P. V eldman, B. Wwanowski and B. Buchner : A Volume-of-Fluid based simulation method for wave impact problems, In : Journal of Computational Physics, 206(2005), pp.363-393.

20) Ararmsa S. A li. : Impact pressure and decay properties of breaking waves, Dr thesis, Gifu University(1996), 96p.

21) Antoci, C., M. Gallati and S. Sibilla : Numerical simulation of fluid-structure interaction by SPH, Computers and Structures, 85(2007), pp.879-890. 
